ARCHITECTURAL

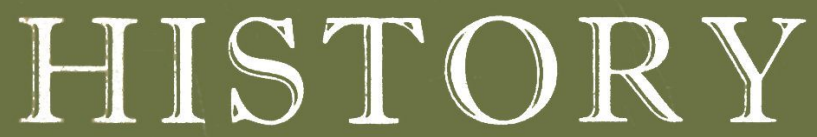

JOURNAL OF THE SOCIETY OF ARCHITECTURAL HISTORIANS OF GREAT BRITAIN * VOLUME $2 * 1959$ https://doi.org/10.1017/S0066622X00004317 Published online by Cambridge University Press 


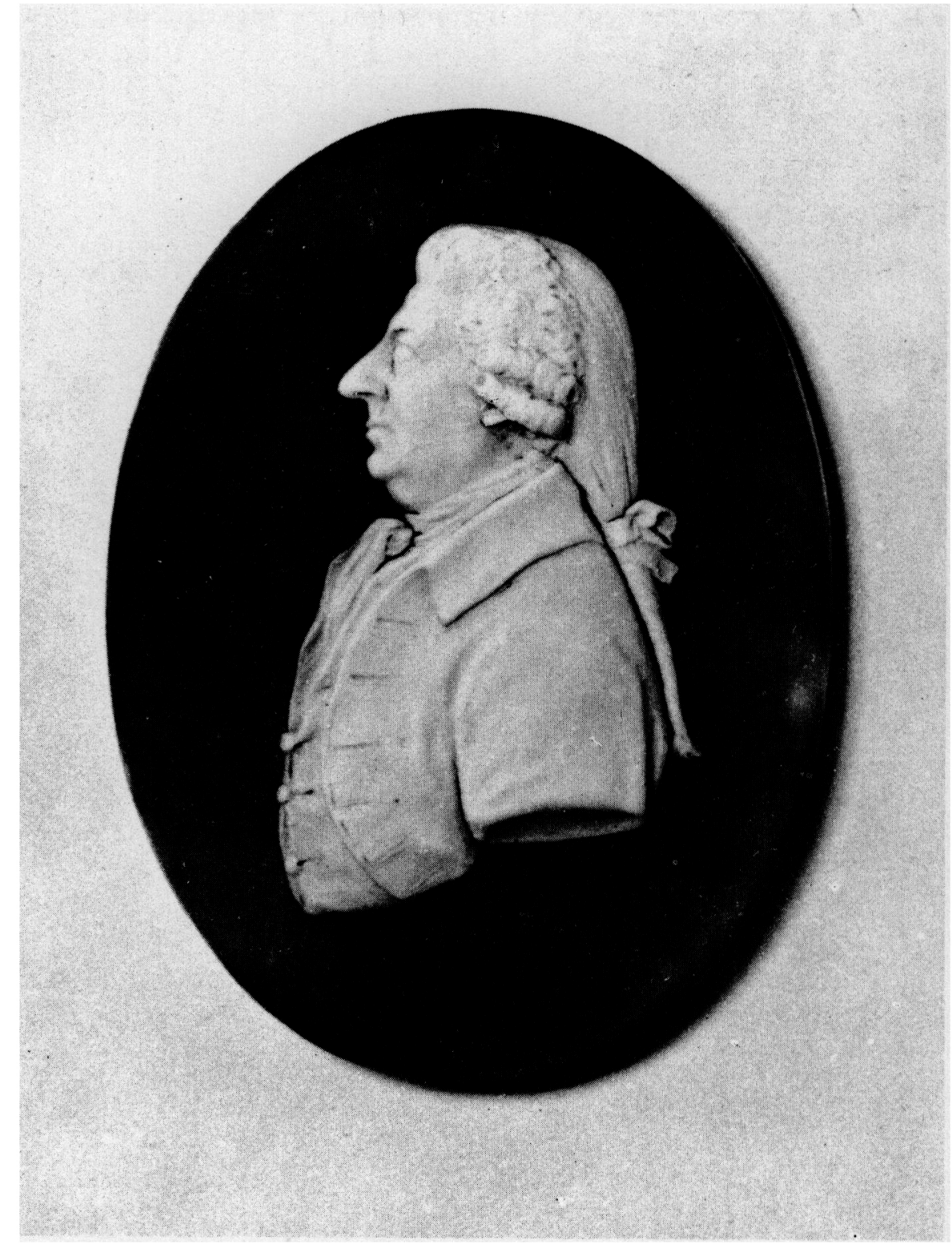

The Alice Hitchcock Medallion, presented to the Society by Professor Henry-Russell Hitchcock in memory of his mother. The medallion, which consists of a Wedgwood portrait of James "Athenian" Stuart, is to be awarded annually by the Society for an outstanding work on architectural history. 


\title{
ARCHITECTURAL HISTORY
} THE JOURNAL OF THE SOCIETY OF ARCHITECTURAL HISTORIANS OF GREAT BRITAIN

\author{
Produced at the School of Architecture \\ King's College, Newcastle upon Tyne \\ UNIVERSITY OF DURHAM \\ and published by
}

The Society of Architectural Historians of Great Britain at

The Institute of Advanced Architectural Studies

MiCKLEGATE, YORK

1959 
EDITORIAL COMMITTEE

Bruce Allsopp

Howard Colvin

J. Quentin Hughes

F. Fielden

F. I. Jenkins

Sir John Summerson

J. P. West-Taylor

(Editor)

Printed by

KING'S COLLEGE PRINTING SECTION

NEWCASTLE UPON TYNE

K.C.P.S. 811.500 .5 .59 


\section{CONTENTS}

The Alice Davis Hitchcock Medallion - - - - Frontispiece

Page

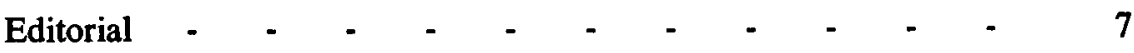

A Note on the Arcading and Sculpture in the South Aisle of Beverley Minster, by Bruce Allsopp - $\quad$ - $\quad-\quad-\quad \cdot \quad 8$

Four Fourteenth-century Building Contracts, by Howard Colvin - 19

Inigo Jones and the Prince's Lodging at Newmarket, by John Harris 26

Catalogue of Drawings of Newgate Gaol in Sir John Soane's

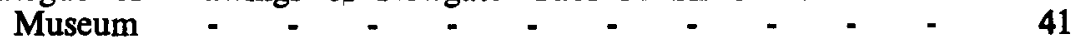

British Transport Historical Records and their Value to the Architectural Historian, by Henry Parris - - - $\quad$ - 50

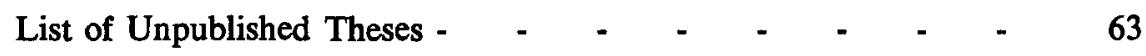

Letter from W. R. Lethaby, c.1930 (Reproduced by courtesy of 68 Arthur Llewellyn Smith, Esq.)

Report of 1958 Annual Meeting - $\quad$ - $\quad$ - $\quad$ - $\quad$ - $\quad$ - $\quad$ - 70

The Constitution of the Society - $\quad+\quad-\quad+\quad-\quad 71$

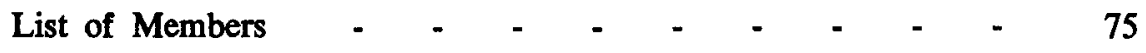

Supplement: Drawings of the Royal Arcade, Newcastle upon Tyne 81 